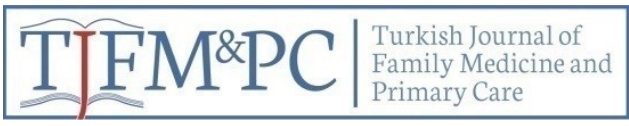

Original Research / Özgün Araştırma

\title{
Examination of Attitudes of Married Women on Domestic Violence
}

\section{Evli Kadınların Aile İçi Şiddete İlişkin Tutumlarının İncelenmesi}

\author{
Arzu Ylldırım ${ }^{1}$, Rabia H. Aşılar ${ }^{2}$, Ilknur A. Avcl ${ }^{3}$
}

\begin{abstract}
Objective: This study was conducted to examine the attitudes of married women towards domestic violence. Method: This descriptive, cross-sectional study was conducted between April and June 2010 with 1,010 women in five Family Healthcare Centers in the province of Erzincan, Turkey. The data were collected using a descriptive questionnaire and the Attitudes Towards Domestic Violence Scale. When analyzing the data, numbers, percentages, minimum and maximum values, means and standard deviations as well as the Mann-Whitney-U, Kruskall Wallis variance and Spearman correlation analyses were used. Results: The average score of married women's Attitude Towards Domestic Violence Scale was 31,6 \pm 7,0 and the entire women were found to have been exposed to verbal/psychological violence, $31,6 \%$ of them to physical violence, $28,3 \%$ to economic violence and $1.4 \%$ to sexual violence. Women who themselves were high school graduates and their husbands were high school and university graduates and had a job, who had no children, who lived in a nuclear family in a city or town, who perceived their income being more than their expenses, who stated that they made decisions together with their husbands and who were married at a more advanced age had more negative attitudes towards violence $(p<0.001 ; p<0.01)$. Conclusion: The attitude of women against domestic violence was at a moderate level and they all were exposed to some kind of violence, verbal/psychological violence being at the top of the list. Nurses and other healthcare professionals should be sensitive about, and take responsibility for, the prevention of domestic violence and strengthening women support systems.
\end{abstract}

Key words: Women, gender, domestic violence, attitude, health professionals

\section{ÖZET}

Amaç: $\mathrm{Bu}$ araştırma, evli kadınların aile içi şiddete ilişkin tutumlarının incelenmesi amacıyla yapılmıştır. Yöntem: Tanımlayıcı-kesitsel türde yapılan bu araştırma Nisan-Haziran 2010 tarihleri arasında, Erzincan il merkezinde bulunan beş Aile Sağlığı Merkezinde 1010 kadın ile yapılmıştır. Verilerin toplanmasında tanımlayıcı soru formu ve Aile İçi Şiddete Yönelik Tutum Ölçeği kullanılmıştır. Verilerin analizinde, sayılar, yüzdelikler, en az ve en çok değerler ile ortalama ve standart sapmaların yanısıra; Mann Whitney-U, Kruskall Wallis varyans ve Spearman korelasyon analizleri kullanılmıştır. Bulgular: Evli kadınların Aile İçi Şiddete Yönelik Tutum Ölçeği puan ortalamasının 31,6 7,0 olduğu, kadınların tamamının sözel/psikolojik, \%31,6'sının fiziksel, \%28,3'ünün ekonomik ve \%1,4'ünün ise cinsel şiddete maruz kaldığı belirlenmiştir. Ayrıca, kendisi lise, eşleri lise ve üniversite mezunu olan, kendisi ve eşi çalışan, çocuğu olmayan, çekirdek ailede ve il veya ilçede yaşayan, gelirini giderinden fazla algılayan, kararları eşi ile birlikte ortak aldığını belirten ve evlenme yaşı ileri olan kadınların şiddete karşı tutumlarının olumsuz olduğu saptanmıştır $(\mathrm{p}<0,001 ; \mathrm{p}<0,01)$. Sonuç: Kadınların, aile içi şiddete karşı tutumlarının orta düzeyde olduğu ve sözel/psikolojik şiddet başta olmak üzere, şiddetin her türüne maruz kaldığ1 belirlenmiştir. Diğer sağlık profesyonelleri ile birlikte hemşireler, aile içi şiddeti önleme ve kadınların destek sistemlerini güçlendirme konularında duyarlı olmalı ve sorumluluk almalıdır.

Anahtar kelimeler: Kadın, toplumsal cinsiyet, aile içi şiddet, tutum, sağlık profesyonelleri

Received Date: 12.03.2019, Accepted Date: 13.05.2019

${ }^{1}$ Erzincan Binali Yıldırım Üniversitesi Sağlık Bilimleri Fakültesi

${ }^{2}$ Erzincan Binali Yıldırım Üniversitesi Sağlı Bilimleri Fakültesi

${ }^{3}$ Ondokuz Mayıs Üniversitesi Sağlık Bilimleri Fakültesi

*Address for Correspondence / Yazışma Adresi: Arzu Yıldırım, Erzincan Binali Yııldırım Üniversitesi Sağlık Bilimleri Fakültesi E-mail: yildirimarzu25@hotmail.com

Yıldırım A, Aşılar HR, Avcı Aİ. Evli Kadınların Toplumsal Cinsiyet Özelliklerinin Aile İçi Şiddete İlişkin Tutumları Üzerine Etkisi. TJFMPC, 2019;13 (4): 407-417.

DOI: $10.21763 /$ tjfmpc.638295 


\section{GİRIŞ}

Toplumsal cinsiyet, kadın ve erkeğin toplumsal olarak belirlenen rolleri ve sorumluluklarını ifade etmektedir. Bu kavram, biyolojik farklılıklardan ziyade toplumun kadın ve erkeği nasıl gördüğünü, nasıl algıladığını, nasıl düşündüğünü ve beklenilen rol ve davranışları göstermektedir. Toplumsal cinsiyet ayrımı ise kadın ve erkeğin yaşamını şekillendirmekte ve sonuçta bu çeşitlilik farklı olmaktan daha fazla anlam taşımaktadır. ${ }^{1}$

Toplumsal cinsiyet eşitsizliği, yoksulluk ve çatışma ortamı gibi faktörler şiddeti ortaya çıkaran toplumsal etkenlerdendir. Bireyin ve ailenin iyilik halinin bozulmasına neden olan, toplumların daha iyi bir sağlık düzeyine ulaşmasını ve sürdürülebilir toplumsal gelişmeyi engelleyen şiddet, giderek artan bir halk sağlığı sorunudur. ${ }^{2}$ Aile içi şiddet her yaşta, her sosyoekonomik ve demografik grupta ortaya çıkmakla birlikte ağırlıklı olarak kadınları ve çocukları etkilemektedir. ${ }^{3}$ Eşler arası şiddet fiziksel, cinsel ve psikolojik zarara neden olan davranış olarak belirtilmektedir ve eşler arası şiddetin en büyük bölümünü erkeğin kadına uyguladığı şiddet olguları oluşturmaktadır. ${ }^{2}$

Toplumda, aile içi şiddetin boyutunu doğru olarak belirlemek güç olabilmektedir. Doğası gereği şiddet olayları, sıklıkla kapalı kapılar ardında yaşanmakta ve genellikle failleri ve bazen de mağdurları tarafından gizlenmekte ve inkar edilmektedir. $^{3}$ Dünya Sağlık Örgütü tarafından 2013 yılında yayınlanan raporda, dünyada kadınların \%35'inin ya eşi veya birlikte yaşadığı kişinin fiziksel ve/veya cinsel şiddetine ya da partneri olmayan bir kişinin cinsel şiddetine maruz kaldığ 1 ve kadın cinayetlerinin \%38'inin kadınların eşi veya birlikte yaşadığı kişi tarafından işlendiği bildirilmiştir. ${ }^{4,5}$ Türkiye'de, 2013-2014 yıllarında yürütülen Kadına Yönelik Aile İçi Şiddet Araştırması sonuçlarına göre ise yaşamının herhangi bir döneminde fiziksel şiddete maruz kaldığını belirten kadınların oranı \%36, son 12 ayda ise \%8'dir. Evlenmiş kadınların \%38'i yaşamlarının herhangi bir döneminde fiziksel ve/veya cinsel, \%44'ü psikolojik şiddete ve her 10 kadından yaklaşık 3'ü de en az bir kez 1srarlı takibe maruz kalmıştır. ${ }^{5,6}$

Kadına yönelik şiddeti doğuran etkenler, toplumsal cinsiyet eşitsizliği temelinde çoklu ve karmaşık bir yapı sergilemektedir. ${ }^{5} \mathrm{Bu}$ doğrultuda aile içi ve eş şiddetini etkileyen bir çok bağlamsal etken bulunmaktadır. Bunlar: kültürel değerler ve inançlar (güç ve kabadayılıkla ilişkilendirilen erkeklik, katı cinsiyet rolleri); toplumsal etkenler (işsizlik, sosyo-ekonomik durum, toplumsal ve coğrafi yalıtım); durumsal etkenler (ailede erkek egemenliği, aile mal varlığının erkek tarafından kontrolü, eşler arasında uyumsuzluk ve çatışma, alkol ve madde kullanımı); çocukluk döneminde eş şiddetine tanık olmak ve istismara uğramaktır. ${ }^{3}$

Toplumsal yapı, şiddeti engelleyici ya da teşvik edici özellik gösterebildiği için ${ }^{2}$ tutumlar kadına yönelik şiddeti etkileyebilmektedir. Tutum, birikimli deneyim yoluyla geliştirilen bilinçli veya bilinçsiz zihinsel kanılara dayalı; belirli bir olgu, kişi ya da objeye karşı lehinde veya aleyhinde bir eğilimi ifade etmektedir. ${ }^{7}$ Mısır'da kırsal bölgede erkeklerin aile içi şiddete yönelik ve şiddeti destekleyen tutumlarını değerlendirmek amacı ile kesitsel toplum temelli yürütülen bir çalışmada, erkeklerin \%57,3'ü bazı durumlarda aile içi şiddetin haklı ve gerekli olduğunu, \%69'u eşlerine karşı çoğunlukla fiziksel şiddet uyguladığını ve \%30.9’u şiddetin eğitim yetersizliğinden kaynaklandığını belirtmiştir. Erkeklerin yalnızca \%7'si cinsiyet eşitliğine önemle destek verdiğini bildirmiştir. ${ }^{8}$

Eş şiddetinin, kadın sağlığı üzerinde ciddi etkileri bulunmaktadır. Avustralya'da 2011'de eş şiddetinin, 25-44 yaş grubundaki kadınlarda herhangi bir risk etkeninden daha fazla hastalık yüküne (hastalık etkisi, engellilik ve erken ölüm) yol açtığı, fiziksel ve veya cinsel eş şiddetine maruz kalan kadınlarda anksiyete bozuklukları (\%35) ve depresif bozukluklar (\%32) başta olmak üzere ruhsal sorunların en fazla hastalık yüküne neden olduğu bildirilmiştir. ${ }^{3}$ Brezilya'da yapılan bir araştırmada, aile içi şiddetin kadınların yaşam kalitesi ile ilişkili olduğu belirlenmiş ve aile içi şiddet olaylarını etkileyen değişkenlerin toplumsal ilişkiler, kadınların tıbbi tedavi alması ve güvenlik olduğu tespit edilmiştir. ${ }^{9}$

İstismara uğrayan kadınlar, hekimleri ve diğer sağlık profesyonellerini potansiyel destek kaynakları olarak tanımlamaktadır. İngiltere'de, 272 birinci basamak klinisyenin aile içi şiddete ilişkin bilgi, tutum ve klinik becerilerini belirlemek amacıyla yapılan bir çalışmada, klinisyenler aile içi şiddet konusunda temel bilgilere sahip olduklarını, istismara uğramış kadınlarla etkileşim konusunda olumlu bir tutum sergilediklerini, ancak aile içi 
şiddet ile ilgili sorular sormaya ya da istismar bildirildiğinde, uygun yönlendirmeleri yapmaya hazır olmadıklarını ifade etmişlerdir. Ayrıca klinisyenlerin \%40'ının yaralanma ile başvuran bir kadına, istismar durumunu ya hiç sormadığı ya da nadiren sorduğu, \%80'inin yerel aile içi şiddet kaynakları hakkında yeterli bilgiye sahip olmadığ1, aile hekimlerinin şiddet konusunda daha donanımlı ve daha bilgili ve hemşirelerden daha fazla sayıda aile içi şiddet vakası tespit ettikleri saptanmıştır. ${ }^{10}$ Lübnan'da, birinci basamakta beş yıldan fazla çalışan ve haftada 100 'den fazla hasta gören hekimlerin aile içi şiddete yönelik tutumlarını, hekimlik rolüne ilişkin algılarını ve tepkilerini etkileyen faktörleri araştırmak amacı ile yapılan niteliksel bir çalışmada da hekimler, aile içi şiddet konusunda önemli bir rol oynayacaklarını düşündüklerini, ancak kişisel güvenlik, hastaları kaybetme ve muhafazakâr bir toplumun normlarına karşı olma konusunda endişe duyduklarını ifade etmişlerdir. Bazı hekimler ise aile içi şiddeti haklı bulduklarını, şiddete sebebiyet verdiği için şiddeti uygulayanı değil, mağduru suçlu gördüklerini ifade etmişlerdir. ${ }^{11}$ Türkiye'de, acil tıp hizmetlerinde çalışan 370 sağlık çalışanı ile yapılan bir çalışmada, katılımcıların \%48,5'inin kadına yönelik şiddeti tanıma ve yönetmede yeterli olduğunu düşündükleri, bu tür vakalarla karşılaştıklarında \%18,5'i mağduru şiddet uygulayanla uzlaştırmaya çalışacaklarını belirtmişlerdir. Bununla birlikte erkek katılımcıların kadına yönelik şiddeti ve cinsiyetçi tutumları daha fazla destekledikleri sonucuna ulaşılmıştır. ${ }^{12}$

Aile içi şiddete müdahale, disiplinler arası işbirliğini gerektiren bir durumdur. $\mathrm{Bu}$ nedenle, hemşireler gerekli durumlarda diğer disiplinlerle işbirliği ve eşgüdüm içerisinde çalışmalıdır. Hemşirelerin, kadına yönelik aile içi şiddete ilişkin rol ve sorumlulukları aile içi şiddetin saptanması, tıbbi tedavi ve bakımın sağlanması, aile içi şiddete maruz kalan kadınla güvenli bir ortamda görüşme, bilgilendirme ve danışmanlık, güvenlik planı oluşturma, kayıt tutma ve gerekli disiplinlere sevk etme girişimlerini içermelidir. ${ }^{13}$

Bu bilgiler doğrultusunda, bu çalışma, evli kadınların aile içi şiddete ilişkin tutumlarının incelenmesi amacıyla yapılmıştır.

\section{YÖNTEM}

\section{Örneklem}

Tanımlayıcı-kesitsel türde yapılan bu araştırma, Nisan-Haziran 2010 tarihleri arasında Erzincan il merkezinde bulunan beş Aile Sağlığı Merkezinde yapılmıştır. Araştırmada herhangi bir örnekleme yöntemi kullanılmamıştır. Araştırmaya, belirtilen tarihler arasında herhangi bir nedenle merkezlere başvuran evli, iletişim kurulabilen, araştırmaya katılmayı kabul eden 1010 kadın alınmıştır.

\section{Kullanılan Araçlar}

Verilerin toplanmasında, tanımlayıcı soru formu ve Aile İçi Şiddete Yönelik Tutum Ölçeği kullanılmıştır.

Tanımlayıcı Soru Formu: Kadınların sosyodemografik (yaş, eğitim durumu, çalışma durumu, çocuk sahibi olma durumu, aile tipi, eşin eğitim ve çalışma durumu, yerleşim yeri, gelir durumu alg1s1) ve baz1 toplumsal cinsiyet özelliklerini (alınan kararlarda söz sahibi olma durumu, şiddete maruz kalma durumu ve maruz kalınan şiddet türleri) içeren toplam 12 sorudan oluşmuştur.

Aile İçi Şiddete Yönelik Tutum Ölçeği (AİŞYTÖ): Şahin ve Dişsiz (2009) tarafından, hemşire/ebe ve sağlık memurlarının aile içi şiddete yönelik tutumlarını belirlemek üzere geliştirilen ve Türkiye'de geçerlilik-güvenilirlik çalışması yapılan ölçeğin sağlık çalışanları dışındaki gruplara da uygulanabileceği gösterilmiştir. Ölçek, toplam 13 madde ve 4 faktörden oluşmaktadır. Bunlar; şiddeti olağanlaştırma (5 madde: 1,2,3,4,5), şiddeti genelleştirme (3 madde: 6,7,8), şiddeti nedenselleştirme (3 madde: 9,10,11) ve şiddeti saklama (2 madde: 12,13)'dır. Ölçek beşli Likert tipi olup, maddeler 1-5 arasında (1-kesinlikle katılmıyorum, 2- katılmıyorum, 3-kararsızım, 4kat1lyorum, 5-kesinlikle katıliyorum) puanlandırılmaktadır. Ölçeğin değerlendirilmesinde, maddeler toplanarak toplam puan elde edilmektedir. Ölçekten alınabilecek en yüksek puan 65, en düşük puan ise 13'tür. Puanlardaki artış şiddete yönelik tutumun olumlu, azalma ise şiddete yönelik tutumun olumsuz olduğunu göstermektedir. Ölçeğin Cronbach- alfa güvenirlik katsayısı 0,72 olarak belirlenmiş ${ }^{14}$, bu araştırmada ise 0,71 olarak saptanmıştır. $\mathrm{Bu}$ 
çalışmada, istatistiksel analizler, ölçek toplam puanı üzerinden yapılmıştır.

\section{Verilerin Toplanması}

Tanımlayıcı soru formunun anlaşılabilirliğini belirlemek için, örneklem dışındaki farklı sosyoekonomik düzeyden 15 kişilik bir gruba önuygulama yapılmış ve gerekli düzeltmelerden sonra soru formunun son şekli araştırma grubuna uygulanmıştır. Veriler, aile sağlığı merkezlerinde görüşme için uygun bir odada kadınlarla yüz, yüze görüşülerek toplanmıştır. Formların doldurulması yaklaşık 15-20 dakikada tamamlanmıştır.

\section{İstatistiksel Analiz}

Verilerin analizinde, sayılar, yüzdelikler, en az ve en çok değerler ile ortalama ve standart sapmalar kullanılmıştır. Ayrıca verilerin normal dağılıma uygunluğu Shapiro-Wilk testi ile değerlendirilmiştir. Veriler, normal dağılıma uygunluk göstermediğinden nonparametrik testler kullanılmıştır. Değişkenler ile AİŞYTÖ puan ortalamaları arasındaki ilişkiyi belirlemede, Mann Whitney-U, Kruskall Wallis varyans ve Spearman korelasyon analizi yapılmıştır. Verilerin değerlendirilmesinde SPSS for Windows 22 paket programı kullanılmış ve $p<0,05$ anlamlılık düzeyi olarak kabul edilmiştir.

\section{Etik İlkeler}

Araştırmaya başlamadan önce Erzincan İl Sağlık Müdürlüğü'nden yazılı izin ve kadınlardan yazılı/sözel onam alınmıştır. Araştırma kapsamına alınan kadınlara, araştırmanın amacı, planı ve yararları açıklanıp, veri toplama aşamasında araştırmadan istedikleri zaman ayrılabilecekleri ifade edilmiş ve gönüllü olanlar çalışmaya dâhil edilmiştir.

\section{BULGULAR}

Kadınların \%51'inin okuryazar, \%92'sinin çalışmadığı, \%91,9'unun çocuğunun olduğu ve \%79,6'sının çekirdek ailede yaşadığı belirlenmiştir. Ayrıca kadınlarının \%29,4'ünün eşinin ilkokul mezunu olduğu, \%82,8'inin eşinin çalıştığ1, \%86,2'sinin il merkezinde yaşadı̆̆ 1 , \%52,5'inin gelirini giderine eşit olarak algıladığı ve \%45,7'sinin evde kararları eşi ile birlikte ortak aldığını belirttiği bulunmuştur (Tablo 1). Kadınların yaş ortalaması $37,1 \pm 11,2 \quad(\min =15, \quad \max =77)$, eşlerinin yaş ortalaması $41,3 \pm 11,6 \quad$ ( $\min =18$, $\max =90)$ yıl; kadınların evlenme yaşı ortalaması $19,9 \pm 3,7$ y1l $(\min =14, \quad \max =50)$, evlilik y1l ortalamas1 ise $16,8 \pm 11,8(\min =1, \max =60)$ olarak belirlenmiştir (Tablo 4). Kadınların AİŞYTÖ toplam puan ortalamalarının $31,6 \pm 7,0 \quad(\mathrm{~min}=13$, $\max =62$ ) olduğu saptanmıştır (Tablo 2).

Kadınların maruz kaldığg şiddet türlerine bakıldığında, evlilik süresince kadınların tamamı sözel/psikolojik, \%31,6's1 fiziksel, \%28,3'ü ekonomik ve \%1,4'ü ise cinsel şiddete maruz kaldığını ifade etmiştir (Tablo 3).

$\mathrm{Bu}$ araştırmada kadınların eğitim düzeyine göre AIŞYTÖ puan ortalamaları arasında anlamlı bir fark olduğu, yapılan ileri analizde (U) okuryazar olmayan ve üniversite mezunu olan grup arasında anlamlı fark olmadığı, tüm gruplar arasında anlamlı bir fark olduğu belirlenmiştir. Buna göre, okur-yazar olmayan $(35,3 \pm 6,0)$ ve üniversite mezunu $(36,3 \pm 6,7)$ olan kadınların AİSYTÖ puan ortalamalarının en yüksek, diğer bir ifade ile şiddete karşı tutumlarının olumlu olduğu (şiddeti onayladıkları) belirlenmiştir $\quad\left(x^{2} \mathrm{KW}\right.$ $=146,373 ; \mathrm{p}<0,001)$.

Çalışan kadınların $(25,18 \pm 6,51)$ AİŞYTÖ puan ortalaması çalışmayan kadınlara $(32,2 \pm 7,1)$ göre anlamlı olarak düşük bulunmuş ve şiddeti onaylamadıkları belirlenmiştir $\quad(U=17491,0$; $\mathrm{p}<0,001)$.

Çocuğu olmayan kadınların $(29,9 \pm 6,4)$ AİŞYTÖ puan ortalamasının çocuğu olanlara $(31,8 \pm 7,4)$ göre anlamlı olarak düşük, şiddete karş1 tutumlarının olumsuz olduğu belirlenmiştir $(\mathrm{U}=32724,5 ; \mathrm{p}<0,001)$.

$\mathrm{Bu}$ araştırmada çekirdek ailede yaşayan kadınların $(31,1 \pm 6,8)$ geniş ailede yaşayanlara $(33,3 \pm 7,3)$ göre AİŞYTÖ puan ortalamasının anlamlı olarak düşük olduğu, şiddeti onaylamadıkları saptanmıştır $(U=6979,0 ; p<0,001)$.

Eşin eğitim durumuna göre, AİŞYTÖ puan ortalamaları arasında anlamlı bir fark olduğu, eşi lise $(30,1 \pm 6,2)$ ve üniversite $(28,3 \pm 6,7)$ mezunu olan kadınların AİŞYTÖ puan ortalamalarının, eşi diğer eğitim düzeylerine sahip olanlara göre düşük ve şiddete karşı tutumlarının olumsuz olduğu saptanmıştır $\left(x^{2} \mathrm{KW}=106,4 ; \mathrm{p}<0,001\right)$. 


\begin{tabular}{|c|c|c|}
\hline Tanımlayıcı özellikler & Sayı & Yüzde \\
\hline \multicolumn{3}{|l|}{ Eğitim durumu } \\
\hline Okur-yazar değil & 62 & 6,1 \\
\hline Okur-yazar & 515 & 51 \\
\hline İlkokul & 117 & 11,6 \\
\hline Ortaokul & 186 & 18,4 \\
\hline Lise & 69 & 6,9 \\
\hline Üniversite & 61 & 6 \\
\hline \multicolumn{3}{|l|}{ Çalışma durumu } \\
\hline Çalışan & 81 & 8 \\
\hline Çalışmayan & 929 & 92 \\
\hline \multicolumn{3}{|l|}{ Çocuk sahibi olma durumu } \\
\hline Var & 928 & 91,9 \\
\hline Yok & 82 & 8,1 \\
\hline \multicolumn{3}{|l|}{ Aile tipi } \\
\hline Çekirdek & 804 & 79,6 \\
\hline Geniş aile & 206 & 20,4 \\
\hline \multicolumn{3}{|l|}{ Eşin eğitim durumu } \\
\hline Okur yazar değil & 16 & 1,6 \\
\hline Okur-yazar & 25 & 2,5 \\
\hline İlkokul & 297 & 29,4 \\
\hline Ortaokul & 190 & 18,8 \\
\hline Lise & 285 & 28,2 \\
\hline Üniversite & 197 & 19,5 \\
\hline \multicolumn{3}{|l|}{ Eşin çalışma durumu } \\
\hline Çalışan & 836 & 82,8 \\
\hline Çalışmayan & 174 & 17,2 \\
\hline \multicolumn{3}{|l|}{ Yerleşim yeri } \\
\hline İl & 871 & 86,3 \\
\hline İlçe & 54 & 5,3 \\
\hline Köy & 85 & 8,4 \\
\hline \multicolumn{3}{|l|}{ Gelir durumu algısı } \\
\hline Gelir giderden az & 431 & 42,7 \\
\hline Gelir gidere eşit & 530 & 52,5 \\
\hline Gelir giderden fazla & 49 & 4,8 \\
\hline \multicolumn{3}{|c|}{$\begin{array}{l}\text { Alınan kararlarda söz sahibi olma } \\
\text { durumu }\end{array}$} \\
\hline Kendi sözü geçer & 90 & 8,9 \\
\hline Eşinin sözü geçer & 413 & 40,9 \\
\hline Her ikisi birlikte karar verir & 462 & 45,7 \\
\hline Aile büyüklerinin sözü geçer & 45 & 4,5 \\
\hline
\end{tabular}




\begin{tabular}{|c|c|c|c|}
\hline AİŞYTÖ & $\begin{array}{c}\text { Alınabilecek Puan } \\
\text { Aralığ }\end{array}$ & $\begin{array}{c}\text { Alınan Puan } \\
\text { Aralığı }\end{array}$ & Ort \pm SS \\
\hline Şiddeti Olağanlaştırma & $5-25$ & $5-25$ & $10,5 \pm 3,0$ \\
\hline Şiddeti Genelleştirme & $3-15$ & $3-15$ & $6,4 \pm 2,4$ \\
\hline Şiddeti Nedenselleştirme & $3-15$ & $3-15$ & $8,0 \pm 2,1$ \\
\hline Şiddeti Saklama & $2-10$ & $2-10$ & $6,6 \pm 2,5$ \\
\hline Toplam & $13-65$ & $13-62$ & $31,6 \pm 7,0$ \\
\hline
\end{tabular}

AİŞYTÖ: Aile İçi Şiddete Yönelik Tutum Ölçeği, Ort.: Ortalama, SS: Standart Sapma

\begin{tabular}{|l|c|c|}
\hline \multicolumn{3}{|c|}{ Tablo 3. Kadınların maruz kaldığı şiddet türlerinin dağılımı (s=1010) } \\
\hline \$Şiddet türleri & Sayı & Yüzde \\
\hline *Sözel/Psikolojik şiddet & & 20,9 \\
\hline Aşağılama, küçümseme, alay & 267 & 30,4 \\
\hline Kıskançlı & 387 & 5 \\
\hline Süphecilik & 64 & 34,9 \\
\hline Bağırma & 444 & 8,8 \\
\hline Sevgi göstermeme & 112 & $\mathbf{1 0 0}$ \\
\hline Toplam & $\mathbf{1 2 7 4}$ & 15,6 \\
\hline Fiziksel şiddet & & 6,1 \\
\hline Tokat & 158 & 1,2 \\
\hline Yumruk & 62 & 4,2 \\
\hline İtme & 12 & 3,4 \\
\hline Tekme & 42 & 1,1 \\
\hline Saç çekme & 34 & $\mathbf{3 1 , 6}$ \\
\hline Isırma & 11 & 8,9 \\
\hline Toplam & $\mathbf{3 1 9}$ & 19,4 \\
\hline Ekonomik şiddet & & 28,3 \\
\hline Hiç para vermeme & 90 & $\mathbf{1 , 4}$ \\
\hline Ekonomik olarak ihmal & 196 & $\mathbf{1 0}$ \\
\hline Toplam & 286 & $\mathbf{1 4}$ \\
\hline Cinsel şiddet & & \\
\hline
\end{tabular}

\$Kadınların tamamı şiddete maruz kalmıştır. *Sorulara birden fazla yanıt verilmiş, yüzdeler n üzerinden alınmıştır.

Eşi çalışan kadınların $(31,03 \pm 6,96)$, eşi çalışmayan kadınlara $(34,2 \pm 6,5)$ göre Aİ̧̧TÖ puan ortalamasının anlamlı olarak düşük ve şiddete karşı tutumlarının olumsuz olduğu belirlenmiştir $\left(x^{2} \mathrm{KW}\right.$ $=106,4 ; \mathrm{p}<0,001)$.

Yaşanılan yere göre, kadınların AİşYTÖ puan ortalamaları arasında anlamlı bir fark olduğu, ileri analizde (U) bu farkın köyde yaşayan kadınlardan kaynaklandığı bulunmuştur. Buna göre köyde $(33,7 \pm 6,3)$ yaşayan kadınların, ilçe $(30,8 \pm 6,5)$ ve ilde $(31,4 \pm 7,1)$ yaşayan kadınlara göre AİŞYTÖ puan ortalamasının anlamlı olarak yüksek ve şiddete karşı tutumlarının olumlu olduğu belirlenmiştir $\left(x_{\mathrm{KW}}^{2}=11,0 ; \mathrm{p}<0,005\right)$. 


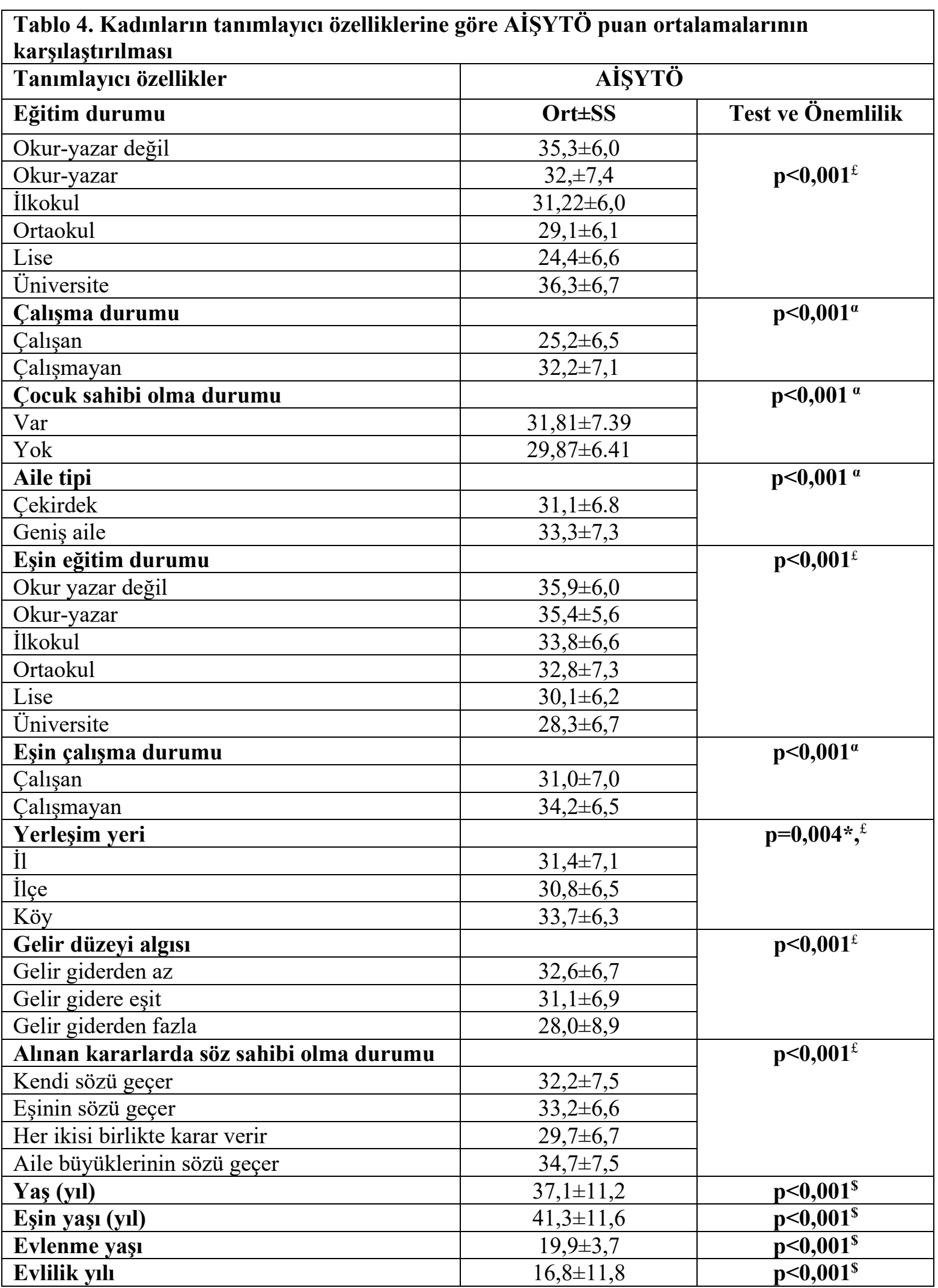

AİŞYTÖ: Aile İçi Şiddete Yönelik Tutum Ölçeği, Ort.: Ortalama, SS: Standart Sapma, *p<0,005

${ }^{\mathfrak{f}}$ Kruskall Wallis varyans analizi, ${ }^{\alpha}$ Mann Whitney-U testi, ${ }^{\$}$ Spearman korelasyon analizi. 
Kadınların gelir düzeyi algılarına göre, AİŞYTÖ puan ortalamaları arasında anlamlı bir fark olduğu, yapılan ileri analizde (U) farkın tüm gruplardan kaynaklandığ 1 saptanmıştır. En düşük AİŞYTÖ puan ortalamasina geliri giderinden fazla olan $(28,0 \pm 8,9)$ kadınların sahip olduğu, başka bir ifade ile şiddete karşı tutumlarının olumsuz olduğu bulunmuştur $\left(\mathrm{x}^{2}{ }_{\mathrm{KW}}=26,4 ; \mathrm{p}<0,001\right)$.

Evde alınan kararlarda söz sahibi olma durumuna göre, kadınların Aİ̧̧YTÖ puan ortalaması arasında anlamlı bir fark belirlenmiştir. Yapılan ileri analizde (U) farkın kararları eşi ile birlikte ortak aldığını belirten kadınlardan kaynaklandığ 1 ve en düşük AIŞYTÖ puan ortalamasına $(29,7 \pm 6,7)$ bu kadınların sahip oldukları, ayrıca kararlarda kendi sözü ve aile büyüklerinin sözünün geçtiğini belirten kadınların puan ortalamasının da anlamlı fark oluşturduğu saptanmıştır $\left(x^{2}{ }_{\mathrm{KW}}=64,7 ; \mathrm{p}<0,001\right)$.

$\mathrm{Bu}$ çalışmada, kadınların yaşı ile AİŞYTÖ puan ortalaması arasında anlamlı bir ilişki saptanmış, yaş arttıkça şiddete karşı tutumun olumlu olduğu bulunmuştur $\left(\mathrm{r}_{\mathrm{s}}=0,201 ; \mathrm{p}<0,001\right)$.

Kadınların eşlerinin yaşı arttıkça, Aİ̧̧YTÖ puan ortalamasının anlamlı olarak arttığ 1 ve şiddeti onayladıkları tespit edilmiştir $\left(\mathrm{r}_{\mathrm{s}}=0,195 ; \mathrm{p}<0,001\right)$.

Kadınların evlenme yaşı arttıkça, Aİ̧̧YTÖ puan ortalamasının anlamlı olarak azaldığı, şiddete karşı tutumlarının olumsuz olduğu belirlenmiştir $\left(r_{s}=-0,214 ; p<0,001\right)$.

Araştırmada, kadınların evlilik yılı arttıkça AISSYTÖ puan ortalamasının anlamlı olarak arttığı, şiddete karşı tutumlarını olumlu olduğu bulunmuştur $\left(\mathrm{r}_{\mathrm{s}}=0,240 ; \mathrm{p}<0,001\right)$ (Tablo 3 ).

\section{TARTISMA}

Kadınlar aile içi şiddet yönünden büyük risk altındadır. Çok boyutlu bir sorun olan kadına yönelik şiddet, yalnızca kadınların sağlığını ve refahını etkilemekle kalmamakta, aynı zamanda toplumu da olumsuz etkilemektedir. Bu çalışmada, evli kadınların aile içi şiddete ilişkin tutumlarının incelenmesi amaçlanmış ve elde edilen sonuçlar literatür doğrultusunda tartışılmıştır.

Toplumun kültürel değerleri, kadın ve çocuklar üzerinde erkeğin etkisini belirlemektedir. ${ }^{2}$ Bir nesneye veya davranışa özgü olarak tanımlanan tutumlar, bireysel öznel değerlendirme süreci yoluyla oluşturulmakta, ancak duygusal tepkilerden ve buna bağlı inançlardan da etkilenmektedir. ${ }^{15} \mathrm{Bu}$ araştırmada, evli kadınların AIŞ̧YTÖ puan ortalamalarının ölçekten alınabilecek en düşük ve en yüksek puanlar dikkate alındığında orta düzeyde olduğu, diğer bir ifade ile aile içi şiddete karş1 tutumlarının orta düzey olduğu söylenebilir. Türkiye'de 16 yaş ve üzerindeki 355 kadın ile yapılan bir çalışmada, kadınların \%49,9'unun aile içi şiddete maruz kaldığ $1, \% 52,1$ 'inin aile içi şiddeti onayladığı ve şiddet görenlerin \%38,6'sının şiddet görmeleri konusunda kendilerini suçladığ 1 bildirilmiştir. ${ }^{16}$ Yine Türkiye'de Şiddeti Önleme ve İzleme Merkezi (ŞÖNIM)'ne eşinden/partnerinden şiddet görerek başvuran 70 kadınla yapılan bir çalışmada da, kadınların \%91,4'ünün şiddetin bazen gerekli olduğunu, \%62,9'unun ise şiddet gören kişinin karşısındakine benzer şekilde davranabileceğini ifade ettiği bildirilmiştir. ${ }^{17}$ Etiyopya'da, amaçlı örnekleme tekniği kullanılarak evli kadınlar arasında toplumun cinsiyete dayalı şiddete yönelik alg1 ve tutumunu değerlendiren nitel bir çalışmada, kadınların çoğu toplumda cinsiyete dayalı şiddetin kabul edilebilir olduğunu, şiddet içeren eylemleri kınamak yerine oldukça hoşgörülü olmak gerektiğini, cinsiyete dayalı şiddetin sonuçlarının önemsiz ve ortadan kaldırılmasının zor olduğunu algılamışlardır. Çalışmada, ayrıca aile içi şiddetin yaygın olduğu, bireylerin tutumunun ve geleneksel normların cinsiyet temelli şiddetin evli kadınlar üzerindeki kabul edilebilirliğini belirlemede önemli rol oynadığ 1 belirlenmiştir. ${ }^{18}$ Nijerya'da, kırsal kesimdeki 15-49 yaş grubunda 3911 kadın ile rastgele örneklem kullanılarak yapılan araştırmada da, kadınların eş şiddetine yönelik tutumlarında sosyo-ekonomik dezavantajların yanı sıra; sosyal, ekonomik, dini ve kültürel faktörlerin etkili olduğu belirtilmiştir. ${ }^{19}$ Çoklu gösterge küme araştırması verileri kullanılarak, 15-49 yaş aralığındaki Vietnamlı kadınlarda aile içi şiddeti destekleyici tutumlara katkıda bulunan sosyoekonomik faktörleri tanımlamak amacı ile yapılan bir çalışmada, aile içi şiddeti kabul etme yaygınlığının 2006-2011 yılları arasında azaldığı $(\% 65,1$ 'den $\% 36,1$ 'e düşmüştür) bildirilmiştir. ${ }^{20}$ Türkiye, Nijerya, Vietnam ve Etiyopya'da yapılan bu araştırma sonuçlarından da anlaşılacağı üzere, kadınların aile içi şiddete yönelik tutumlarında coğrafik, toplumsal, kültürel, ekonomik, inanç ve zaman gibi faktörlerin etkili olabileceği söylenebilir. 
$\mathrm{Bu}$ araştırmada, evli kadınların tamamının sözel/psikolojik, \%31,6’sının fiziksel, \%28,3'ünün ekonomik ve \%1,4'ünün ise cinsel şiddete maruz kaldığı belirlenmiştir. Canlı ve Özyurda (2018) tarafından yapılan bir çalışmada da, evli kadınların \%40’ının evliliği süresinde en az bir kez eşi tarafindan şiddet gördüğü ve en fazla duygusal şiddete uğradığı bildirilmiştir. ${ }^{21}$ Türkiye'de, farklı illerde yapılan diğer çalışmalarda, bu çalışma sonucu ile karşılaştırıldığında, sözel/psikolojik şiddet dışında kadınların diğer şiddet türlerine maruz kalma oranının daha yüksek olduğu saptanmıştır. ${ }^{22-25}$ Yapılan başka bir çalışmada da, kadınların büyük bir bölümünün $(\% 59,7)$ şiddeti fiziksel şiddet olarak tanımladıkları, ekonomik ve cinsel şiddeti tanımlayanların olmadığı belirlenmiştir. ${ }^{26}$

Brezilya'da yapılan kesitsel toplum temelli hane halkı araştırmasında, 424 kadının \%54,4'ünün aile içi şiddete ${ }^{9}$; Avustralya'da ise altı kadından ve 16 erkekten birinin 15 yaşından itibaren önceki ya da şuan birlikte yaşadığı eşi tarafından fiziksel ve/veya cinsel şiddete maruz kaldığı bildirilmiştir. ${ }^{3}$ Türkiye, Brezilya ve Avustralya'da yapılan bu farklı araştırma sonuçlarında, kadınların eş şiddetine maruz kalma düzeylerinin yaygın olduğu ve şiddetin her türünü farklı düzeylerde yaşadıkları görülmektedir. $\mathrm{Bu}$ araştırma ve bildirilen çalışmaların farklı sonuçlarında, bölgesel, toplumsal, kültürel, ekonomik ve zaman gibi faktörlerin etkili olabileceği düşünülebilir.

$\mathrm{Bu}$ araştırmada, kendisi lise, eşleri lise ve üniversite mezunu olan, kendisi ve eşi çalışan, çocuğu olmayan, çekirdek ailede ve il veya ilçede yaşayan, gelirini giderinden fazla algılayan, kararları eşi ile birlikte ortak aldığını belirten ve evlenme yaşı ileri olan kadınların şiddete karşı tutumlarının olumsuz olduğu, şiddeti onaylamadıkları; ancak kendisinin ve eşinin yaşı ve evlilik yılı fazla olan kadınların şiddete yönelik tutumlarının olumlu olduğu tespit edilmiştir. Yoksulluk, yaşanılan sosyal çevre, şiddeti teşvik eden kültürel etkenler, toplumsal yalıtılmışlık, işsizlik ve evlilikte uyumsuzluk ve çatışma gibi etkenler şiddetin ortaya çımasını kolaylaştırmaktadır. ${ }^{2}$ Türkiye'de, kadınların eğitim düzeyi ile evlilik yaşı, doğurganlık yaşı ve sayısı, işgücüne katılım ve kazancın kullanımı arasında ilişkiler olduğu ve bu doğrultuda eğitimin kadınların güçlenmesinin önemli bir dayanağı olduğu gösterilmektedir. ${ }^{1}$ Türkiye'de yapılan bir çalışmada da, düşük sosyoekonomik düzeydeki bölgede yaşayan ve eğitim düzeyi sekiz yıl ve altında olan kadınların, kadına yönelik şiddeti daha çok haklı gördüğü saptanmıştır. ${ }^{16}$ Ayrıca, Türkiye'de yapılan diğer çalışmalarda; aile içi şiddete daha çok eğitim düzeyi düşük kadınların ${ }^{24,27}$ başka bir çalışmada en fazla ilkokul mezunu, en az ise okur-yazar olmayan kadınların maruz kaldığı $1^{22}$; diğer bir çalışmada ise eğitim düzeyi arttıkça fiziksel şiddete maruz kalma oranının arttı̆̆ bildirilmektedir. ${ }^{25}$ Bunun yanı sıra, aile içi şiddet görmüş 19 kadın ile yarı yapılandırılmış sorular eşliğinde, yüz yüze görüşülerek yapılan bir çalışmada da, kadınların ilk evliliklerinin 15-26 yaş aralığında olduğu, yoksulluğu, geçim sıkıntısını ve işsizliği gördükleri şiddetin ilk nedenleri arasında belirttiği gösterilmiştir. Küçük yaşta evlenen bu kadınların tamamının, kalabalık ve yoksul ailelerden geldiği, geçim sıkıntısı nedeniyle eğitimlerini sürdürmedikleri ve kadınların eşlerinin eğitim düzeylerinin de düşük olduğu bildirilmiştir. ${ }^{28}$ Tokuç ve arkadaşlarının (2010) çalışmasında da, kalabalık evde yaşama, çalışmama, düşük sosyoekonomik düzey, ataerkil yap1 ve geleneksel değerlerin aile içi fiziksel şiddet için risk etkenleri olduğu sonucuna varılmıştır. ${ }^{29}$ Ağrı ilinde aile içi şiddete maruz kalmış kadınların profilini incelemek amacı ile yapılan betimleyici bir çalışmada, 20-30 yaş arası kadınların daha çok şiddetle karşılaştıkları, aile içi şiddetten dolayı polise başvuran kadınların çoğunun daha sonra boşandıkları, çoğu kadının doğuştan sahip oldukları haklarının neler olduğunu ve şiddete maruz kaldıklarında ne yapmaları gerektiğini bilmedikleri saptanmıştır. ${ }^{30}$

Vietnam'da yapılan bir çalışmada da, kadınların aile içi şiddeti hoş görmeleriyle ilişkili sosyoekonomik faktörler yaş, ekonomik durum, eğitim düzeyi ve yaşanılan bölge olarak tespit edilmiştir. Eğitim düzeyi düşük olan kadınların, şiddeti destekleyici tutum gösterdikleri ve kadınların eğitim düzeyinin aile içi şiddete karşı tutumlarını etkileyen en önemli belirleyici olduğu bildirilmiştir. ${ }^{20}$ Benzer şekilde Nijerya'da yapılan bir çalışmada, eğitim ve gelir düzeyi düşük kadınların eş şiddetini daha çok hoş gördüğü sonucuna ulaşılmıştır. ${ }^{19}$ Avustralya'da yerel toplumda aile içi şiddet riskini artıran etkenlerin konutun kötü ve kalabalık olması, maddi zorluklar, düşük eğitim ve gelir düzeyi, işsizlik, aile ve toplumda uyuşmazlığın yüksek düzeyde olması, merkezden uzak bir yerde yaşamak, hizmetlere 
yetersiz erişim, kötü fiziksel ve ruhsal sağlık, engellilik, çocuklukta şiddet ve istismar deneyimi olduğu belirtilmiştir. Ayrıca lisansüstü mezunu kadınların, lisans mezunu olanlara göre eş şiddetine daha çok maruz kaldığı bildirilmiştir. ${ }^{3}$

Şiddete başvuran kişiler ve şiddete maruz kalanlar, genellikle ergenler ve genç erişkinlerdir. ${ }^{2}$ Avustralya'da da gençlerin, kadına yönelik şiddeti destekleyen tutumlara sahip olma olasılığının daha yüksek olduğu bildirilmiştir. ${ }^{3}$ Öyekçin ve arkadaşları (2012)'nın çalışmasında, eşin yaşı ve evlilik süresinin artması kadınların herhangi bir tür şiddete maruz kalmasında koruyucu etkenler olarak bulunmuştur. ${ }^{27} \mathrm{Bu}$ araştırmada ise kendisinin ve eşinin yaşı ve evlilik yılı fazla olan kadınların şiddete yönelik tutumlarının olumlu olması bölgesel, toplumsal, kültürel, ekonomik ve zaman gibi etkenlerin yanısıra, evlilik yılı arttıkça eşler arası çatışma ve uyumsuzluğun artma olasılığı ile açıklanabilir.

\section{SONUÇ}

$\mathrm{Bu}$ araştırmada, evli kadınların aile içi şiddete karşı tutumlarının orta düzeyde olduğu, kadınların tamamının sözel/psikolojik, \%31,6'sının fiziksel, $\% 28,3$ 'ünün ekonomik ve \%1,4'ünün ise cinsel şiddete maruz kaldığı belirlenmiştir. Kendisi lise, eşleri lise ve üniversite mezunu olan, kendisi ve eşi çalışan, çocuğu olmayan, çekirdek ailede ve il veya ilçede yaşayan, gelirini giderinden fazla algılayan, kararları eşi ile birlikte ortak aldığını belirten ve evlenme yaşı ileri olan kadınların şiddete karşı tutumlarının olumsuz olduğu, şiddeti onaylamadıkları; kendisinin ve eşinin yaşı ve evlilik yılı fazla olan kadınların şiddete yönelik tutumlarının olumlu olduğu tespit edilmiştir. $\mathrm{Bu}$ araştırmada da, görüldüğü üzere kadınlar sözel/psikolojik şiddet başta olmak üzere şiddetin her türünü yaşamakta ve eğitim ve gelir durumu başta olmak üzere toplumsal, ekonomik ve kültürel yapı şiddete karşı tutumu etkilemektedir. Çeşitli ve kalıcı sağlık durumlarına ve toplumsal sorunlara neden olan kadına yönelik şiddetle mücadelede, eğitim ve ekonomi gibi etkenlerle toplumsal cinsiyet eşitsizliklerinin ortadan kaldırılması olasıdır. Bu bağlamda, sağlık profesyonellerinin şiddet durumlarını tanımlama ve çözümüne ilişkin duyarlı olması ve gerekli müdahalelerde bulunması önemlidir.

\section{Araştırmanın Sınırlılığı}

$\mathrm{Bu}$ araştırmada iki sınırlılık bulunmaktadır. Birincisi, araştırma kesitsel özellikte olduğundan neden ve sonuç arasındaki ilişkiyi değerlendirmede doğru sonuçları elde etmenin güç olmasıdır. İkincisi ise, araştırma örneklemi Erzincan'daki bütün evli kadınları kapsamadığından, sonuçların evli kadınların tamamını temsil etmemesidir.

\section{KAYNAKLAR}

1. Akın A, Bahar Özvarış Ş. Toplumsal cinsiyet (gender) kavramı ve sağlığa etkileri. Halk Sağlığı Temel Bilgiler 1. Edit: Güler Ç, Akın L. Hacettepe Üniversitesi Yayınları, 3. Bask1Tipk1 Basım, Ankara, 2015; s: 220-230.

2. Paksoy Erbaydar N. Şiddet, nedenleri ve sonuçları. Halk Sağlığı Temel Bilgiler 3. Edit: Güler Ç, Akın L. Hacettepe Üniversitesi Yayınları 2015; 3. Bask1-Tıpk1 Basım, Ankara, s: $1838-1849$.

3. Australian Institute of Health and Welfare. Family, domestic and sexual violence in Australia 2018. Cat. no. FDV 2. Canberra: AIHW.

https://www.aihw.gov.au/getmedia/d1a8d479a39a-48c1-bbe2-4b27c7a321e0/aihw-fdv02.pdf.aspx? inline=true. Erişim: 07.01.2019.

4. WHO. Global and regional estimates of violence against women: prevalence and health effects of intimate partner violence and nonpartner sexual violence. 2013. https://apps.who.int/iris/bitstream/handle/1066 5/85241/WHO_RHR_HRP_13.06_eng.pdf?seq uence=1. Erişim: $07 . \overline{01} \cdot 201 \overline{9}$

5. Kadına Yönelik Şiddetle Mücadele Ulusal Eylem Planı (2016-2020). T.C. Aile ve Sosyal Politikalar Bakanlığı Kadının Statüsü Genel Müdürlüğü. $\quad 2016$. file://C:/Users/acer/Downloads/93e7f03f6494a 0c80d7837e44f7813c8.pdf Erișim: 14.05.2019.

6. Türkiye'de Kadına Yönelik Aile İçi Şiddet Araştırması. Ankara, 2015. T.C. Aile ve Sosyal Politikalar Bakanlığı Kadının Statüsü Genel Müdürlüğü. Hacettepe Üniversitesi Nüfus Etütleri Enstitüsüs:325-327. http://www.hips.hacettepe.edu.tr/KKSATRAnaRaporKitap26Mart.pdf Erişim: 14.05.2019.

7. Altmann TK. Attitude: A Concept Analysis. Nursing Forum 2008; 43:144-150.

8. Hassan EE, Seedhom AE, Mahfouz EM. Men's perception of domestic violence, rural minia, Egypt. Open Journal of Preventive Medicine 2016; 6:106-114.

9. Lucena KDT, Vianna RPT, Nascimento JAD, Campos HFC, Oliveira ECT. Association between domestic violence and women's 
quality of life. Rev. Latino-Am. Enfermagem 2017; 25, e2901:1-8.

10. Ramsay J, Rutterford C, Gregory A, Dunne D, Eldridge S, Sharp D, et al. Domestic violence: knowledge, attitudes, and clinical practice of selected UK primary healthcare clinicians. Br J Gen Pract. 2012;62:e647-55.

11. Usta J, Feder G, Antoun J. Attitudes towards domestic violence in Lebanon: a qualitative study of primary care practitioners. Br J Gen Pract. 2014;64:e313-20.

12. Çalıkoglu EO, Aras A, Hamza M, Aydin A, Nacakgedigi O, Koga PM. Sexism, attitudes, and behaviors towards violence against women in medical emergency services workers in Erzurum, Turkey. Glob Health Action 2018;11,1524541:1-8.

13. Efe ŞY. Acil servis hemşirelerinin kadına yönelik aile içi şiddete ilișkin rol ve sorumlulukları. F.Ü. Sağ.Bil.Tıp Derg 2012; 49-54.

14. Şahin N. Dişsiz M. Sağlık Çalışanlarında Aile İçi Şiddete Yönelik Tutum Ölçeği geliştirme çalışması. Uluslararası İnsan Bilimleri Dergisi 2009; 263-274.

15. Understanding and measuring attitudes. https://www2.gov.scot/resource/doc/175356/00 91396.pdf. Erişim: 24.12.2018.

16. Naçar M, Baykan Z, Poyrazoğlu S, Çetinkaya F. Kayseri ilinde iki sağlı ocağı bölgesi'nde kadına yönelik aile içi şiddet. TAF Prev Med Bull 2009; 8:131-138.

17. Başkale H, Sözer A. Eşinden/partnerinden şiddet gören kadınların şiddet algısı ve mağduriyet nedenleri. TAF Prev Med Bull 2015; 14:468-474.

18. Muche AA, Adekunle AO, Arowojolu AO. Gender-based violence among married women in Debre Tabor Town, Northwest Ethiopia: A Qualitative Study. Afr J Reprod Health 2017; 21:102-109.

19. Antai DE, Antai JB. Attitudes of women toward intimate partner violence: a study of rural women in Nigeria. Rural Remote Health. 2008;8, 996:1-12.

20. Trinh OT, Oh J, Choi S, To KG, Van Do D.Changes and socioeconomic factors associated with attitudes towards domestic violence among Vietnamese women aged 1549: findings from the Multiple Indicator Cluster Surveys, 2006-2011. Glob Health Action. 2016; 9,29577:1-7.

21. Canlı S, Özyurda F. Ankara ili gölbaş1 ilçesinde doğurgan çağdaki kadınlarda kadına yönelik şiddet ve depresyon ilişkisi. Nobel Med 2018; 14: 31-39.

22. Tanrıverdi G, Şıpkın S. Canakkale'de sağlık ocaklarına basvuran kadınların eğitim durumunun şiddet görme düzeyine etkisi. Frrat Tıp Dergisi 2008;13: 183-187.
23. Nedime Köşgeroğlu N, Çulha İ, Öz Z, Yılmaz A. Şiddet karşısında kadınların davranışlarının incelenmesi. Akademik Sosyal Araştırmalar Dergisi 2015; 3(9): 342-350.

24. Kumcağız H, Avcı İA, Talay T, Gürkan S, Kinsiz DN. Samsun şiddet önleme ve izleme merkezine başvuran şiddet mağduru kadınların başvuru durumları ve gereksinimleri. MANAS Sosyal Araştırmalar Dergisi 2018; 7: 401-414.

25. Korkmaz S, Korucu T, Yıldız S, Kaya Ş, İzci F, Atmaca M. Psikiyatri hastalarında aile içi şiddetin sıklığı ve ilişkili faktörler. Düşünen Adam The Journal of Psychiatry and Neurological Sciences 2016; 29:359-366.

26. Güler N, Tel H, Tuncay FÖ. Kadının aile içinde yaşanan şiddete bakışı C. Ü. Tıp Fakültesi Dergisi 2005; 27:51-56.

27. Öyekçin DG, Yetim D, Şahin EM. Kadına yönelik farklı eş şiddeti tiplerini etkileyen psikososyal faktörler. Türk Psikiyatri Dergisi 2012;23:75-81.

28. Aşkın EÖ, Aşkın U. Kadına yönelik aile içi şiddet ve yoksulluk ilişkisi: aile içi şiddet mağduru kadınlar üzerine bir araştırma. Kapadokya Akademik Bakış 2018; 1:16-37.

29. Tokuç B, Ekuklu G, Avcioglu S. Domestic violence against married women in Edirne. Journal of Interpersonal Violence 2010; 25:832-47.

30. Doğutaş A, Doğutaş C. Türkiye'de aile içi şiddet: Ağrı ili örneği. Sosyal Politika Çalışmaları 2013; 13:91-109. 